TROPICAL MEDICINE

\title{
Sexually transmitted infections in pregnancy: prevalence, impact on pregnancy outcomes, and approach to treatment in developing countries
}

\author{
S Mullick, D Watson-Jones, M Beksinska, D Mabey
}

Sex Transm Infect 2005;81:294-302. doi: 10.1136/sti.2002.004077

Sexually transmitted infections (STIs) are common in the developing world. Management of STls in pregnancy in many developing countries has, however, been complicated by the lack of simple and affordable diagnostic tests. This review examines the prevalence and impact on pregnancy outcome of STls in developing countries and recommends approaches to management of STIs in pregnancy for resource poor settings.

See end of article for authors' affiliations

Correspondence to: Saiqa Mullick, The Population Council Frontiers in Reproductive Health, Hyde Park Lane Manor, EG001 Edinburgh Gate, Box 411744 Craighall 2024, Johannesburg, South Africa; smullick@pcjoburg. org.za

Accepted for publication 12 November 2004
$\mathrm{S}$ exually transmitted infections (STI) have been associated with a number of adverse pregnancy outcomes including spontaneous abortion, stillbirth, prematurity, low birth weight (LBW), postpartum endometritis, and various sequelae in surviving neonates.

Preterm birth and low birth weight are major determinants of infant morbidity and mortality, especially in developing countries where neonatal intensive care facilities are not often available. In one cross sectional study in Nairobi, Kenya, the incidence of LBW $(<2500 \mathrm{~g})$ was $7.5 \%$, and the perinatal mortality in LBW children was 222 per 1000 live births. ${ }^{1}$

STIs, including HIV, are believed to be of particular importance in determining pregnancy outcome in the developing world because the prevalence of infection is so high. ${ }^{2}$ Cross sectional, randomised trials and retrospective cohort studies of antenatal clinic attenders in Africa have found that up to $40 \%$ of pregnant women have trichomoniasis and bacterial vaginosis, 2.5$17 \%$ have serological evidence of syphilis, ${ }^{3-6}$ while the prevalence of gonorrhoea and chlamydia ranges from $2-7 \%$ and $3-29 \%$, respectively (table 1).

Most published studies on the relation between STIs and pregnancy outcome have come from developed countries. This paper reviews the evidence from both developed and developing countries, but focuses particularly on the few developing country studies. Literature was identified using several methods: the Pubmed database was searched using keywords "sexually transmitted infections," "pregnancy," and "antenatal." Abstracts were first reviewed to select publications that reported on pregnancy outcomes. Papers reporting studies in developing countries and those most recently published were selected for review. WHO and CDC websites were also searched for relevant guidelines. Key experts and reviewers suggested additional literature including project reports and published material for review.

\section{CLINICAL PRESENTATION AND CONSEQUENCES IN PREGNANCY}

Examining the impact of STI on pregnancy outcome is difficult. For ethical reasons it is not usually possible to prospectively study the effects of an untreated STI once the diagnosis has been made. Many studies have therefore been retrospective in design, where data have been collected on STIs and birth outcomes at or after delivery, and where it may have been difficult to control for other confounding factors earlier in the pregnancy that affect pregnancy outcome.

\section{ANTIBIOTIC TREATMENT AND PREGNANCY OUTCOME}

Perhaps the best evidence of the impact of maternal infection on pregnancy outcome is from studies of presumptive antibiotic treatment in pregnancy. A randomised controlled trial in the United States showed that treatment with erythromycin between 26 and 30 weeks gestation reduced the incidence of premature rupture of membranes from $16-6 \% \quad(p<0.001) .^{7}$ Two studies in Africa have also shown a benefit of antibiotic therapy in pregnancy. A single dose of ceftriaxone $250 \mathrm{mg}$ intramuscularly given to pregnant women in Nairobi between 28 and 32 weeks gestation participating in a randomised, double blind placebo controlled clinical trial led to a significant increase in mean birth weight $(3.21 \mathrm{~kg} v 3.06 \mathrm{~kg}, \mathrm{p}=0.01)$, and nonsignificant reductions in the incidence of low birth weight (LBW) $(4.0 \% \vee 9.2 \%, \mathrm{p}=0.08)$ and of postpartum endometritis $(3.8 \% \quad v \quad 10.4 \%$, $\mathrm{p}=0.05) .{ }^{8}$ In a randomised clinical trial in the Rakai District of Uganda, a single oral dose of azithromycin $1 \mathrm{~g}$, cefixime $400 \mathrm{mg}$, and metronidazole $2 \mathrm{~g}$, which led to a reduced prevalence of STIs, was associated with significant reductions in the incidence of neonatal death (rate ratio (RR) $0.83,95 \%$ CI 0.71 to 0.97 ) and low birth weight (RR 0.68, 0.53 to 0.86 ) and a

Abbreviations: aOR, adjusted odds ratio; $A N C$, antenatal clinic; BFP, biological false positive; BV, bacterial vaginosis; HSV, herpes simplex virus; IUGR, intrauterine growth retardation; LBW, low birth weight; MTCT, mother to child transmission; ON, ophthalmia neonatorum; PROM, premature rupture of the membranes; RPR, rapid plasma reagin; RR, rate ratio; STI, sexually transmitted infections; VCT, voluntary counselling and testing 


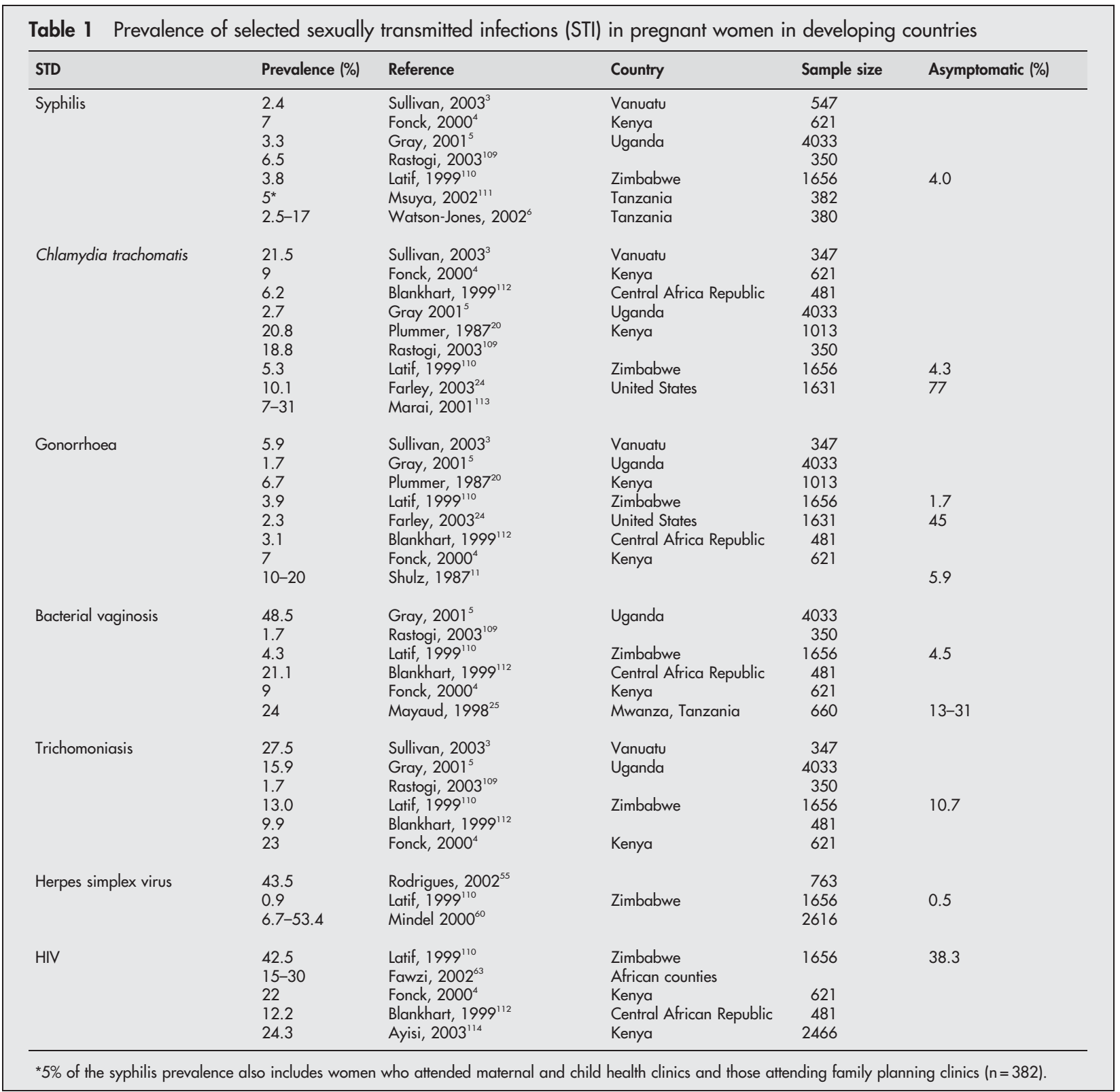

non-significant reduction in preterm delivery (RR 0.77, 0.56 to 1.05$).^{5}$

\section{Syphilis}

Syphilis has long been known to be an important risk factor for adverse pregnancy outcome. ${ }^{9-11}$ The natural history of syphilis acquired in pregnancy is believed to follow the sequential stages of primary, secondary, and latent syphilis that have been observed in untreated, non-pregnant adult cases.

Left untreated, syphilis has a dramatic impact on pregnancy outcome. The consequences of untreated maternal infection include stillbirth, LBW, preterm birth and also congenital infection in a proportion of surviving infants. Historically, one third of pregnancies are believed to result in second trimester spontaneous abortion or perinatal death, one third in a congenitally infected infant, and one third in an uninfected infant. ${ }^{10}$ Data from developing countries confirm that maternal syphilis still remains an extremely important cause of perinatal morbidity and mortality. ${ }^{6-14}$ The most significant consequence of untreated syphilis in resource poor settings is stillbirth but the infection has also been associated with LBW, preterm birth, and intrauterine growth retardation (IUGR) in Africa. ${ }^{6}{ }^{15}$ As in developed countries, mothers with high non-treponemal test titres, as seen in earlier stages of infection, are most at risk of having an adverse pregnancy outcome. ${ }^{6}{ }^{16}$

The impact of untreated syphilis in pregnancy at the population level may be considerable. In a prospective population based study in Malawi and a retrospective cohort study in Tanzania, $21 \%$ of perinatal deaths, $26-51 \%$ of stillbirths, $24 \%$ of preterm live births, $17 \%$ of all adverse pregnancy outcomes, and $11 \%$ of neonatal deaths have been attributed to untreated high titre (a rapid plasma reagin $(\mathrm{RPR})$ test titre of $\geqslant 1: 8$ and a positive treponemal assay) maternal syphilis. ${ }^{6}{ }^{15}$

\section{Chlamydia trachomatis}

Chlamydia trachomatis infection in pregnancy leads to cervicitis and cervical discharge but a high proportion of women are asymptomatic. Information on the impact of untreated chlamydial infection on pregnancy outcome has mainly come 
from non-developing countries. The infection has been associated with stillbirth, premature delivery, premature rupture of the membranes, and LBW. Three large prospective studies of the impact of $C$ trachomatis on pregnancy outcome have been reported from the United States. A study of 801 women enrolled between 22 weeks and 30 weeks gestation found that $C$ trachomatis infection was associated with both intrauterine growth retardation (adjusted odds ratio (aOR) 2.4, 95\% CI 1.3 to 4.2 ) and preterm delivery (aOR 1.6, 95\% CI 1.0 to 2.5 ). ${ }^{17}$ A study of 534 women found that $C$ trachomatis infection was associated with low birth weight (aOR $2.7,95 \%$ CI 1.3 to 5.7 ), premature rupture of membranes (aOR 2.4, 95\% CI 1.1 to 5.4) and preterm labour (<34 weeks) (aOR 4.0, 95\% CI 1.7 to 9.2). ${ }^{18}$ However, a third study involving 1365 women found no association between cervical $C$ trachomatis infection and adverse pregnancy outcome. ${ }^{19}$ In Nairobi, C trachomatis infection was found to be associated with postpartum endometritis. $^{20}$

Maternal $C$ trachomatis infection can also affect the neonate, leading to infant pneumonia and ophthalmia neonatorum $(\mathrm{ON})^{21} ; 30-50 \%$ of infants born to infected women will develop chlamydial $\mathrm{ON}$, which is usually less severe than gonococcal ON. Cross sectional and prospective studies in Nairobi and the Gambia found the incidence of chlamydial $\mathrm{ON}$ to be 8.1 and 2.7 per 100 live births, respectively. ${ }^{22} 23$

\section{Neisseria gonorrhoeae}

The clinical pattern of gonorrhoea in pregnant women is similar to non-pregnant women, with up to $45 \%$ of cases being asymptomatic. ${ }^{24}$ In an antenatal clinic in Tanzania, symptoms of vaginal discharge, itching, and lower abdominal pain were no more common in women with than in women without cervical infection with Neisseria gonorrhoeae or $C$ trachomatis. ${ }^{25}$ Documented sequelae of untreated $N$ gonorrhoeae infection in pregnancy noted in case reports include preterm delivery, premature rupture of the membranes, LBW, postpartum endometritis, and gonococcal $\mathrm{ON}^{26}$

A case-control study of women delivering in hospital in Nairobi, Kenya, enrolled 166 women who delivered infants weighing $<2500 \mathrm{~g}$, and 175 control women. $N$ gonorrhoeae was isolated from $11 \%$ of cases and $4 \%$ of controls (OR2.9, 95\% CI 1.2 to 7.2 ). ${ }^{27}$ The authors concluded that gonorrhoea was responsible for $14 \%$ of cases of LBW in this population. A prospective study in South Africa looked at the relation between gonorrhoea diagnosed at the first antenatal clinic attendance and pregnancy outcome in 167 women. Five of nine women with gonorrhoea delivered a preterm infant compared with 24 of 158 uninfected women (RR 6.0, 95\% CI 1.5 to 34.0$)$. Women with gonorrhoea delivered significantly smaller babies (mean weight $2252 \mathrm{~g} v 2,970 \mathrm{~g}, \mathrm{p}<0.005) .{ }^{13}$ Gonorrhoea has also been associated with upper genital tract infection in postpartum women in a prospective study in Kenya. $^{20}$

Gonococcal ON occurs in 30-50\% of infants born to infected mothers. The incidence of gonococcal ON was 3.6 per 100 live births in Nairobi and $2.1 \%$ in the Gambia. ${ }^{22}{ }^{23}$ Gonococcal ON is a severe disease that may lead to corneal ulceration or perforation, and hence to blindness. A large controlled clinical trial in Nairobi found that ON could be prevented by instilling either $1 \%$ silver nitrate solution, or $1 \%$ tetracycline ointment into the eyes of infants at the time of delivery. ${ }^{28}$ However, since that study was conducted, the prevalence of tetracycline resistant strain of $N$ gonorrhoeae has increased dramatically in many parts of the developing world and $2.5 \%$ povidone-iodine solution appears to be an effective alternative. $^{29}$

\section{Bacterial vaginosis}

Bacterial vaginosis (BV) is the most prevalent cause of vaginal discharge in developing countries. Up to $50 \%$ of pregnant women have been found to have BV in sub-Saharan Africa. ${ }^{5250}$ In developed countries it has been implicated as a cause of preterm birth, LBW, premature rupture of the membranes (PROM), postpartum sepsis, and spontaneous miscarriage. Treatment with oral metronidazole or clindamycin has been shown to reduce the incidence of preterm delivery in women with BV in case-control, prospective, and controlled clinical trials. ${ }^{31-37}$ In the clinical trial in Rakai, treatment with single dose metronidazole, combined with azithromycin $1 \mathrm{~g}$ and cefixime $400 \mathrm{mg}$, reduced the incidence of LBW and neonatal death. ${ }^{5}$ In a multicentre randomised placebo controlled trial in Indonesia, $2 \%$ clindamycin vaginal cream administered to women with BV at 14-26 weeks gestation, the results showed that this was effective for treating BV but did not reduce the incidence of preterm delivery or LBW as it did not eradicate upper genital tract infection. $^{38}$

There have been few studies of the impact of BV on pregnancy outcomes in developing countries. BV was associated with premature delivery in a prospective study in Indonesia, especially when diagnosed early in the second trimester between 16-20 weeks gestation. ${ }^{39}$ No effect of BV was seen later in pregnancy, in contrast with studies in the United States. BV may have most impact on pregnancy when combined with another potential risk factor such as previous preterm or LBW delivery or when there is co-infection with Trichomonas vaginalis. ${ }^{340}$

\section{Trichomoniasis}

Trichomonas vaginalis infection is highly prevalent in antenatal clinic (ANC) attenders in many developing countries (table 1 ). The WHO estimates that $T$ vaginalis accounts for approximately half of all curable sexually transmitted diseases worldwide. ${ }^{2}$ The primary symptom of trichomoniasis in women is vaginal discharge ${ }^{41}{ }^{42}$ but approximately half of all women will be asymptomatic. ${ }^{25} 4243$

$T$ vaginalis has been associated with preterm delivery and LBW in prospective cross sectional and cohort studies..$^{41}{ }^{44-46}$ Similar findings from a case-control study have been observed in Africa where $T$ vaginalis in pregnant Congolese women was associated with delivery of a LBW infant. ${ }^{47}$ It has been estimated that $T$ vaginalis may be responsible for $20-25 \%$ of cases of premature delivery in Africa. ${ }^{48}$ However, treatment of asymptomatic $T$ vaginalis infection with metronidazole in a randomised controlled trial failed to reduce the incidence of preterm delivery in mothers in the United States. ${ }^{49}$

\section{Herpes simplex virus}

Herpes simplex virus (HSV) type 2 has an extremely high prevalence in resource constrained settings, especially in subSaharan Africa where up to $75 \%$ of women aged over 25 years may be infected. ${ }^{50}{ }^{51}$ The proportion of genital ulcers caused by HSV-2 is believed to be increasing in Africa ${ }^{52}{ }^{53}$ and this may be due to its synergistic relation with HIV infection. HSV has been shown to be associated with HIV acquisition in a cross sectional population based sample, an unmatched case-control study nested within a randomised trial cohort and a meta-analysis of 31 studies $^{54-56}$ and clinical recurrences are more frequent in HIV infected individuals. The virus is usually vertically transmitted to the neonate from an infected mother during delivery. As such, the optimal strategy for reducing the morbidity of neonatal herpes is to prevent the neonate from acquiring HSV infection at delivery. A metaanalysis of prospectively designed, randomised, clinical trials detailing the use of aciclovir in pregnancy for women with HSV found that antiviral prophylactic treatment with aciclovir beginning at 36 weeks gestation was effective in 
Table 2 Estimated risk and timing of mother to child transmission of HIV

\begin{tabular}{|c|c|c|c|}
\hline \multirow[b]{2}{*}{ Timing } & \multicolumn{3}{|c|}{ Transmission rate $(\%)$} \\
\hline & No breastfeeding & $\begin{array}{l}\text { Breastfeeding } \\
\text { through } 6 \text { months }\end{array}$ & $\begin{array}{l}\text { Breastfeeding } \\
\text { through } \\
\text { 18-24 months }\end{array}$ \\
\hline During pregnancy & $5-10$ & $5-10$ & $5-10$ \\
\hline During labour & $10-20$ & $10-20$ & $10-20$ \\
\hline \\
\hline Early (first 2 months) & & $5-10$ & $5-10$ \\
\hline Late (after 2 months) & & $1-5$ & $5-10$ \\
\hline Overall & $15-30$ & $25-35$ & $30-45$ \\
\hline
\end{tabular}

reducing clinical HSV recurrences at the time of delivery, caesarean delivery, recurrent genital herpes, and the risk of viral shedding at delivery. ${ }^{57}$

Neonatal herpes is a severe illness presenting with pulmonary disease, seizures, fever, intracranial findings, and a high case fatality rate following contact with infected genital secretions during delivery. ${ }^{58}$ One prospective cohort study in the United States found that 5\% of women from whom HSV was isolated at the time of labour had neonates with HSV infection. ${ }^{59}$ Risks of viral shedding and transmission to the infant are greatest when the mother has primary genital lesions during delivery, especially if she acquires infection towards the end of her pregnancy, ${ }^{60}$ in which case $5-50 \%$ of infants will be infected, ${ }^{61}{ }^{62}$ and lower for recurrent herpes. There are few data on the proportion of pregnant women in developing countries who acquire HSV during pregnancy or on the incidence or prevalence of neonatal HSV.

\section{Human immunodeficiency virus}

In many African settings, HIV is now the most prevalent STI in pregnant women. Overall, $15-30 \%$ of women attending prenatal care clinics are infected with HIV. ${ }^{63}$ UNAIDS reports prevalences between $18-39 \%$ in southern Africa. In east Africa prevalence seems to be declining from 30\% in Uganda in 1990 to $9 \%$ in 2002. In much of west and central Africa, HIV prevalence remains lower than other parts of the continent. ${ }^{64}$

As well as sequelae in the mother, maternal HIV infection, examined in prospective cohort and cross sectional studies, has an independent effect on birth outcome, especially where there is also chorioamnionitis. ${ }^{65}{ }^{66}$ HIV has been associated in case-control and prospective studies with both LBW and stillbirth $^{67}$ and with spontaneous abortion. ${ }^{13}$ An increased risk of preterm delivery in HIV positive mothers compared to HIV negative mothers has also been observed ${ }^{68}{ }^{69}$ The impact of HIV on pregnancy outcome is therefore likely to be significant in high prevalence settings. With an HIV seroprevalence of $16 \%, 19 \%$ of adverse pregnancy outcomes in a large prospective study in Nairobi were attributable to HIV. ${ }^{70}$

The most significant sequela of maternal HIV infection in pregnancy is mother to child transmission (MTCT) of HIV (table 2). Without intervention, rates of MTCT range from $15-30 \%$ without breastfeeding and rise to $30-45 \%$ with prolonged breastfeeding. ${ }^{71}$ MTCT is responsible for $90 \%$ of HIV infection in children worldwide. ${ }^{72}$ It is estimated that 5$10 \%$ of MTCT of HIV results from intrauterine transmission, $10-20 \%$ takes place during delivery, while post-delivery transmission accounts for $5-20 \% .^{73}$ In Africa, duration of breastfeeding, ${ }^{74}$ elevated breast milk sodium levels, ${ }^{75}$ mastitis, maternal viral load, ${ }^{76}$ and non-exclusive breastfeeding ${ }^{77}$ are all risk factors for HIV transmission via breast milk. The risk of MTCT of HIV in the breastfed population is estimated to range from $25 \%$ to $48 \%{ }^{78}$

\section{RECOMMENDATIONS FOR MANAGEMENT IN PREGNANCY IN RESOURCE POOR SETTINGS}

Table 3 summarises the recommended management of STIs in pregnancy in resource poor settings.

\section{Screening for STI in pregnancy-syphilis and HIV}

There are two main situations where screening for the management of STI in pregnancy is an option for resource poor countries. This is because there are cheap screening tests available for the diagnosis of both maternal syphilis and HIV infection.

Given the impact maternal syphilis has on pregnancy outcome, screening and treatment of syphilis in pregnant women at least once during pregnancy should be performed. In most resource poor developing countries, the RPR test is the most common screening assay. This test is cheap and simple although, like other non-treponemal tests, it is susceptible to false positive reactions from other maternal infections or autoimmune disease. These include common conditions like pregnancy, infection, measles, and malaria. Biological false positive (BFP) reactions are common in malaria endemic areas and may account for up to $30 \%$ of reactive RPR tests. ${ }^{6}$ Although the CDC recommends screening at the first ANC visit and again in the third trimester in high prevalence areas, ${ }^{79}$ many developing countries are only able to screen once during pregnancy owing to late attendance of women for antenatal care, the long turn around times from taking blood to getting results, and the cost of screening more than once. The WHO and CDC recommended treatment regimen is a single intramuscular dose of 2.4 MU benzathine penicillin for primary, secondary, and early latent syphilis infection, with three doses for late latent syphilis or syphilis of unknown duration..$^{79}{ }^{80}$ This is often not implemented since many women fail to re-attend for treatment or attend too late in pregnancy to complete the course of treatment. ${ }^{81} 82$

A South African study where women were asked to come back 14 days after testing for results found that the mean number of days to return was 20 and almost a fifth of women were not notified ${ }^{83}$ Onsite screening, where RPR testing is done on site at the ANC and treatment is given at the same visit, does at least assure that women get at least one dose of benzathine penicillin in pregnancy at the time of testing and avoids delays in initiating treatment because of long turn around times for results and women not returning for results. $^{284}$ Another South African study suggests that pregnancy outcome is better in women who receive three rather than one dose of benzathine penicillin, although this may have been because women receiving fewer than three doses were mostly treated late in the third trimester. ${ }^{164}$ Pregnancy outcomes were similar for women treated for syphilis with single dose benzathine penicillin compared to women without serological syphilis in a recent prospective cohort study in Tanzania. ${ }^{85}$ This intervention was found to be extremely cost effective, ${ }^{86}$ but did not address late congenital 


\begin{tabular}{|c|c|}
\hline STI & Treatment in pregnancy \\
\hline Syphilis & $\begin{array}{l}\text { Benzathine penicillin } 2.4 \text { million units by intramuscular injection. Three } \\
\text { weekly doses recommended in latent syphilis of unknown duration. }\end{array}$ \\
\hline Chlamydia & $\begin{array}{l}\text { Erythromycin } 500 \mathrm{mg} \text { orally four times a day for } 7 \text { days, or azithromycin } \\
1 \mathrm{~g} \text { orally single dose, or amoxycillin } 500 \mathrm{mg} \text { orally three times a day for } \\
7 \text { days. }\end{array}$ \\
\hline Gonorrhoea & $\begin{array}{l}\text { Cefixime } 400 \mathrm{mg} \text { orally as single dose, or ceffriaxone } 125 \mathrm{mg} \text { by } \\
\text { intramuscular injection. }\end{array}$ \\
\hline \multirow[t]{2}{*}{ Bacterial vaginosis and trichomoniasis } & Preferable after the first trimester \\
\hline & $\begin{array}{l}\text { Metronidazole } 200 \mathrm{mg} \text { or } 250 \mathrm{mg} \text { orally three times a day for } 7 \text { days, or } \\
\text { metronidazole gel } 0.75 \% \text {, one full applicator }(5 \mathrm{~g} \text { ) intravaginally twice a } \\
\text { day, or clindamycin } 300 \mathrm{mg} \text { orally twice a day for } 7 \text { days. For } \\
\text { trichomoniasis } 2 \mathrm{~g} \text { metronidazole stat recommended as first line } \\
\text { treatment. }\end{array}$ \\
\hline \multirow[t]{3}{*}{ HSV-2 } & Primary infection only \\
\hline & $\begin{array}{l}\text { Aciclovir } 200 \mathrm{mg} \text { orally five times a day for } 7 \text { days, or aciclovir } 400 \mathrm{mg} \\
\text { orally three times a day for } 7 \text { days. } \\
\text { Recurrent infection }\end{array}$ \\
\hline & $\begin{array}{l}\text { Famciclovir } 125 \mathrm{mg} \text { orally three times a day for } 5 \text { days, or valaciclovir } \\
500 \mathrm{mg} \text { twice a day for } 5 \text { days. }\end{array}$ \\
\hline \multicolumn{2}{|c|}{$\begin{array}{l}\text { Cautions: } \\
\text { - Doxycycline, tetracycline, ciprofloxacin, norfloxancin, and ofloxacin should be avoided in pregnancy and } \\
\text { when breast feeding. } \\
\text { - Erythromycin estolate is contraindicated in pregnancy because of drug related hepatoxicity; only erythromycir } \\
\text { base or erythromycin ethylsuccinate should be used. }\end{array}$} \\
\hline
\end{tabular}

syphilis or serological cure in the mothers. Further research on what constitutes an adequate treatment regimen in pregnancy is needed.

There is evidence of the safety and efficacy of short course antiretroviral prophylaxis regimens for prevention of MTCT of HIV from a number of developing countries. ${ }^{87-90}$ Women who are identified as being infected during pregnancy and who have clinical indications for their own therapy should be given the appropriate regimen based on the current WHO recommendations for resource poor settings shown in table $4 .^{90-92}$ There is evidence that viral suppression is less likely in postpartum women given nevirapine containing antiretroviral regimens in those women who received nevirapine during pregnancy. ${ }^{93}$ Pregnant women should therefore now be encouraged to attend for voluntary counselling and testing (VCT) for HIV infection. Initial studies in Africa have shown that uptake of this service may be high. Zambian health employees trained in VCT counselled 17263 pregnant women, of whom $72 \%$ were tested and $24 \%$ of those tested were HIV seropositive. ${ }^{94}$ A large study in four African countries showed that of 22000 antenatal clients, slightly over $13000(61 \%)$ received pretest counselling and $7280(33 \%)$ were tested, although this was highly variable by centre (25-90\%). ${ }^{95}$ In Kenya and Zambia between $20-50 \%$ of women who were tested did not get their results. ${ }^{95}$ This attrition can significantly dilute the impact of interventions for PMTCT.

Post-test counselling of an HIV positive pregnant woman will include advice on breastfeeding. The WHO policy on breastfeeding is summarised as follows. ${ }^{9697}$

- Exclusive breastfeeding should be promoted and supported for 6 months. This applies to women known not to be HIV infected and those of unknown status.

- When replacement feeding is acceptable, feasible, affordable, sustainable and safe, avoidance of all breastfeeding by HIV infected mothers is recommended; otherwise exclusive breastfeeding is recommended during the first months of life.

- To minimise the risk of HIV transmission, breastfeeding should be discontinued as soon as it is feasible, taking the woman's situation into account (including risk of replacement feeding).

\section{Syndromic management of STIs}

In the resource constrained settings of many developing countries, laboratory diagnosis to confirm the aetiology of an STI related symptom is not a practical option. Simple and cheap criteria such as Gram stained vaginal smears or clinical criteria can be used to screen for $T$ vaginalis using a wet preparation or $\mathrm{BV}^{98}{ }^{99}$; in reality even this is beyond the reach of most ANC services in resource poor settings. With the exception of syphilis, HIV, $T$ vaginalis, and $\mathrm{BV}$, there are currently no cheap and reliable screening tests for other STIs. Screening using culture, ELISA, and polymerase chain reaction testing are not feasible and are too costly.

Where services are offered for the treatment of STIs in pregnancy in developing countries, this should rely on syndromic management, based on the provision of treatment for the main organisms that cause specific signs and symptoms (syndromes) associated with certain STIs. Vaginal discharge and genital ulceration are the most frequent syndromes encountered in pregnancy in developing countries. Management of STIs using this approach alleviates the need for expensive laboratory testing and helps healthcare workers to standardise the treatment for each syndrome. ${ }^{100}$ Syndromic management algorithms have several limitations including the fact that they will miss asymptomatic infections. ${ }^{101}$ There are also particular limitations with the use of syndromic management algorithms for the treatment of vaginal discharge as these are particularly poor 
Table 4 Recommendations for use of antiretroviral (ARV) drugs in pregnant women in different clinical scenarios in resource constrained settings

\begin{tabular}{|c|c|}
\hline Clinical situation & Recommendation \\
\hline $\begin{array}{l}\text { Newly diagnosed HIV infected pregnant } \\
\text { women without indication for ARV treatment }\end{array}$ & $\begin{array}{l}\text { Mother } \\
\text { - ZDV } \pm 3 T C+N V P \text { from } 32 \text { weeks gestation, through delivery } \\
\text { (I), (2), (3); stop NVP and continue ZDV + 3TC for } 3 \text { days after } \\
\text { delivery } \\
\text { alternatively: ZDV + } 3 T C \text { from } 34-36 \text { weeks boosted with } \\
\text { single dose NVP at onset of labour } \\
\text { alternatively: ZDV from } 34-36 \text { weeks boosted with single } \\
\text { dose NVP at onset of labour } \\
\text { Single dose NVP in settings where none of the more potent } \\
\text { ARV combinations are feasible or available } \\
\text { Infant } \\
\text { Single dose NVP within } 72 \text { hours of delivery and one week } \\
\text { daily ZDV (extend ZDV for a second week with a second dose } \\
\text { of NVP 5-7 days after the first one if ZDV + 3TC + NVP was } \\
\text { the maternal regimen and breastfeeding has been initiated) } \\
\text { - If delivery occurred within } 2 \text { hours of maternal single dose of } \\
\text { NVP, infant should receive an additional dose of NVP } \\
\text { immediately after birth as well as the routine dose within } \\
72 \text { hours }\end{array}$ \\
\hline
\end{tabular}

Newly diagnosed HIV infected women, with indications for ARV treatment, who may become pregnant

Exclude pregnancy before starting treatment Avoid EFZ Prefer ZDV $+3 T C \pm$ NVP regimen.

Newly diagnosed HIV infected pregnant women with indications for ARV treatment

Newly diagnosed HIV infected pregnant women, with indications for ARV treatment, who did not initiate therapy during pregnancy

- received short course MTCT prophylaxis

- did not receive any MTCT prophylaxis

HIV infected pregnant women newly diagnosed at the time of delivery

Delay start of treatment until after the first trimester of pregnancy Proceed as for non-pregnant adults (1), (2), (3) except EFV

In both cases proceed as for non-pregnant adults (WHO guidelines) with first line regimen recommended

Initiate ARV treatment as soon as possible, including in postpartum period

If there is time, offer rapid test; if no time, rapid test as soon as possible (and acceptable) after delivery.

If test positive, initiate post-exposure prophylaxis in infant: single dose NVP within 72 hours of delivery plus 1 week ZDV.

HIV infected women on ARV treatment for their own disease

Exclude pregnancy before starting treatment. EFV should be avoided in women who can potentially become pregnant Discontinue drugs with teratogenic potential (EFV) or with known adverse potential for the pregnant mother (d4Tiddl)

Consider switching to regimens which include ZDV, 3TC or NVP

EFV, efavirenz; NVP, nevirapine; 3TC, lamivudine; ZDV, zidovudine.

(1) Start NVP with half dose for the first 2 weeks as recommended for adults in WHO guidelines.

(2) Monitor closely clinical and biochemical tolerance in the first month of ARV use

(3) Stop NVP in case of NVP associated toxicity, continue ZDV only until labour

Source: World Health Organization. ${ }^{91}$

at identifying women with cervicitis. In order to reduce the number of women with cervicitis a "risk assessment" approach has been used, and in some settings has been able to reduce the proportion of women overtreated. ${ }^{101}$ However, this approach still lacks sensitivity and specificity and should not be used as a diagnostic or screening tool. ${ }^{100}$ The effectiveness of syndromic management also depends on the healthcare seeking behaviour of the local population, the integration of STI treatment services within ANC services, and on the efficacy of the drugs chosen. Choosing appropriate drugs for STI treatment should depend on local antibiotic sensitivities but these are not known in many resource poor settings. Syndromic management guidelines are currently under review for the management of genital HSV infection, ${ }^{101}$ but are unlikely to affect the current management of HSV in pregnancy unless there is evidence of genital ulceration during the pregnancy. In this situation, women would be treated for syphilis, chancroid, and HSV syndromically. There are no guidelines for prevention of neonatal HSV in most resource poor settings and there are few data on the efficacy of syndromic management regimes for preventing adverse birth outcomes.

\section{Other strategies to control STI in pregnancy}

Other strategies to reduce the impact of STI in pregnancy have included vaginal washing with chlorhexidine to reduce MTCT of HIV in Nairobi. ${ }^{102}$ This showed no overall reduction in intrapartum MTCT of HIV. There have been several studies of presumptive antibiotic treatment in pregnancy. A Kenyan trial of a single presumptive dose of cefetamet-pivoxil versus placebo in women with a previous history of LBW or stillbirth found lower rates of LBW, gonorrhoea at delivery, and postpartum endometritis in women who received the antibiotic. ${ }^{103}$ A larger randomised mass treatment trial of a single cycle of presumptive treatment (azithromycin $1 \mathrm{~g}$, cefixime $400 \mathrm{mg}$, and metronidazole $2 \mathrm{~g}$ ) in Rakai, Uganda, resulted in significant reductions in maternal cervical and vaginal infections and infant $\mathrm{ON}^{104}$ The rates of early neonatal mortality and LBW were also significantly reduced. ${ }^{5}$

In neonates, the WHO recommends that all cases of conjunctivitis in the newborn should be treated for both $N$ gonorrhoeae and $C$ trachomatis. The recommended treatment regimen for gonococcal conjunctivitis is ceftriaxone $50 \mathrm{mg} / \mathrm{kg}$ by intramuscular injection as a single dose to a maximum of $125 \mathrm{mg}$ or alternatively kanamycin $25 \mathrm{mg} / \mathrm{kg}$ as a single dose 
by intramuscular injection to a maximum of $75 \mathrm{mg}$. Neonatal chlamydial conjunctivitis should be treated with erythromycin syrup, $50 \mathrm{mg} / \mathrm{kg}$ per day orally, in four divided doses for 14 days or alternatively trimethoprim $40 \mathrm{mg}$ with sulfamethoxazole $200 \mathrm{mg}$ orally twice a day for 14 days. ${ }^{115}$ Prophylactic silver nitrate, tetracycline or erythromycin eye drops are recommended for infants in populations with high prevalence of $C$ trachomatis and gonorrhoea, ${ }^{104}{ }^{105}$ although this simple intervention is rarely implemented.

Contact tracing, or partner notification, is recommended as an integral part of STI control, including the management of STI in pregnancy. There have been few evaluations of this strategy in the developing world. Studies in sub-Saharan Africa have generally shown low attendance of contacts for syphilis treatment. ${ }^{86}$ A concerted health education campaign in Zambia managed to increase the proportion of contacts attending. ${ }^{106}$ Whether this was sustained long term and what proportion were infected are not known. The social consequences of passing a contact notification slip to a sexual partner have not been measured in developing countries where gender inequality may mean that these can seriously compromise the relationship. This has been highlighted in Kenya where $10 \%$ of women who informed their partners of their HIV status experienced relationship disruption or violence. ${ }^{107}$ Information on the acceptability, effectiveness, and consequences of contact tracing for syphilis and other STI in developing countries is clearly needed.

\section{CONCLUSION}

In summary, there is a high prevalence of STIs in many developing countries. These continue to have an impact on pregnancy outcome. The approach to diagnosis and management is likely to differ from country to country depending on available resources. Most developing countries rely on the syndromic approach to manage STIs in pregnancy. This approach, however, is notoriously poor in identifying infections particularly with $N$ gonorrhoeae and $C$ trachomatis and will miss a high proportion of infection because a significant proportion of infections are asymptomatic. Risk assessment approaches have been used to reduce the proportion of women with cervicitis who are overtreated using the syndromic management approach but this approach still lacks sensitivity and specificity. Further, the syndromic approach currently does not address HSV, which is becoming increasingly common. Recent evidence from a prospective study of women with symptomatic STIs in Ethiopia showed that genital ulcer disease was significantly associated with treatment failure using syndromic management. ${ }^{108}$

There is an urgent need for affordable, rapid, point of care screening tests for STI screening in resource constrained antenatal care settings. Studies have confirmed the effectiveness of antenatal screening and treatment for syphilis and HIV on pregnancy outcome. Integration of antenatal screening services for these infections and the provision of syndromic management for other STIs in antenatal clinics should be prioritised.

\section{ACKNOWLEDGEMENTS}

The authors would like to acknowledge the contributions of Ms Michele Seibou, Population Fellow, Michigan University and Ms Sibekezelo Msomi of the Reproductive Health and HIV Research Unit.

\section{Authors' affiliations}

S Mullick, The Population Council, Frontiers in Reproductive Health, Hyde Park Lane Manor, Edinburgh Gate, Craighall, Johannesburg, South Africa

D Watson-Jones, London School of Hygiene and Tropical Medicine, London, UK and African Medical and Research Foundation, Mwanza, Tanzania
M Beksinska, Reproductive Health Research Unit, Durban, Suite 1301 , Maritime House, Salmon Grove Durban, South Africa

D Mabey, London School of Hygiene and Tropical Medicine, Keppel Street, London, WCIE 7HT, UK

Series editor: David Lewis

\section{REFERENCES}

1 Mati J, Aggarwal V, Lucas S, et al. The Nairobi birth survey. 1. The study design, the population and outline results. J Obstet Gynecol East Cent Afr 1982;1:132-9.

2 World Health Organization. Global prevalence and incidence of selected curable sexually transmitted infections: overview and estimates. Geneva: WHO, 2001.

3 Sullivan EA, Abel M, Tabrizi S, et al. Prevalence of sexually transmitted infections among antenatal women in Vanuatu, 1999-2000. Sex Transm Dis 2003;30:362-6.

4 Fonck K, Kidula N, Jaoko W, et al. Validity of the vaginal discharge algorithm among pregnant women and non-pregnant women in Nairobi, Kenya. Sex Transm Infect 2000;76:33-8.

5 Gray H, Wabwire-Mangen F, Kigozi G, et al. Randomized trial of presumptive sexually transmitted disease therapy during pregnancy in Rakai, Uganda. Am J Obstet Gynecol 2001;185:1209-17.

6 Watson-Jones D, Changalucha J, Balthazar G, et al. Syphilis in pregnancy in Tanzania. I. Impact of maternal syphilis on outcome of pregnancy. J Infect Dis 2002;186:940-7.

7 McGregor JA, French Jl, Richter R, et al. Cervicovaginal microflora and pregnancy outcome: results of a double-blind, placebo-controlled trial of erythromycin treatment. Am J Obstet Gynecol 1990;163(Pt 1):1580-91.

8 Temmerman M, Njagi E, Nagelkerke N, et al. Mass antimicrobial treatment in pregnancy. A randomized, placebo-controlled trial in a population with high rates of sexually transmitted diseases. J Reprod Med 1995;40:176-80.

9 Fiumara NJ, Fleming WL, Downing JG, et al. The incidence of prenatal syphilis at the Boston City Hospital. N Engl J Med 1952;247:48-52.

10 Ingraham NR. The value of penicillin alone in the prevention and treatment of congenital syphilis. Acta Derm Venereol Suppl 1950;31(Suppl 24):60-87.

11 Schulz KF, Cates W Jr, O'Mara PR. Pregnancy loss, infant death, and suffering: legacy of syphilis and gonorrhoea in Africa. Genitourin Med 1987;63:320-5.

12 Watts TE, Larsen SA, Brown ST. A case-control study of stillbirths at a eaching hospital in Zambia, 1979-80: serological investigations for selected infectious agents. Bull World Health Organ 1984;62:803-8.

13 Donders GGG, Desmyter J, De Wet DH, et al. The association of gonorrhoea and syphilis with premature birth and low birth weight. Genitourin Med 1993:69:98-101.

14 Temmerman M, Lopita Ml, Sanghvi HC, et al. The role of maternal syphilis, gonorrhoea and HIV-1 infections in spontaneous abortion. Int J STD AIDS 1992;3:418-22.

15 McDermott J, Steketee R, Larsen S, et al. Syphilis-associated perinatal and infant mortality in rural Malawi. Bull World Health Organ 1993;71:773-80.

16 Donders GGG, Desmyter J, Hooft P, et al. Apparent failure of one injection of benzathine penicillin $G$ for syphilis during pregnancy in human immunodeficiency virus-seronegative African women. Sex Transm Dis 1997;24:94-101.

17 Investigators of the Johns Hopkins Study of Cervicitis and Adverse Pregnancy Outcome. Association of Chlamydia trachomatis and Mycoplasma hominis with intrauterine growth retardation and preterm delivery. Am J Epidemiol 1989;129:1247-57.

18 Graveft MG, Nelson HP, DeRoven T, et al. Independent associations of bacterial vaginosis and Chlamydia trachomatis infection with adverse pregnancy outcome. JAMA 1986;256:1899-903.

19 Harrison HR, Alexander ER, Weinstein L, et al. Cervical Chlamydia trachomatis and mycoplasmal infections in pregnancy. Epidemiology and outcomes. JAMA 1983;250:1721-7.

20 Plummer FA, Laga M, Brunham RC, et al. Postpartum upper genital tract infections in Nairobi, Kenya: epidemiology, etiology and risk factors. J Infect Dis 1987; 156:92-8.

21 Beem MO, Saxon EM. Respiratory tract colonisation and a distinctive pneumonia syndrome in infants infected with Chlamydia trachomatis. N Engl J Med 1977;296:306-10.

22 Laga M, Plummer FA, Nzanze H, et al. Epidemiology of ophthalmia neonatorum in Kenya. Lancet 1986:2:1145-9.

23 Mabey D, Hanlon P, Hanlon L, et al. Chlamydial and gonococcal ophthalmia neonatorum in the Gambia. Ann Trop Paediatr 1987;7:177-80.

24 Farley TA, Cohen DA, Elkins W. Asymptomatic sexually transmitted diseases: the case for screening. Prev Med 2003;36:502-9.

25 Mayaud P, Uledi E, Cornelissen J, et al. Risk scores to detect cervical infections in urban antenatal clinic attenders in Mwanza, Tanzania. Sex Transm Infect 1998;74(Supp 1):5139-46.

26 Lacey CJ, Milne JD. Preterm labour in association with Neisseria gonorrhoeae: case reports. Br J Vener Dis 1984;60:123-14.

27 Elliott B, Brunham RC, Laga M, et al. Maternal gonococcal infection as a preventable risk factor for low birth weight. J Infect Dis 1990;161:531-56.

28 Laga M, Plummer FA, Piot P, et al. Prophylaxis of gonococcal and chlamydial ophthalmia neonatorum. A comparison of silver nitrate and tetracycline. N Engl J Med 1988;318:653-7.

29 Isenberg SJ, Apt L, Wood M. A controlled trial of povidone-iodine as prophylaxis against ophthalmia neonatorum. N Engl J Med 1995;332:562-6. 
30 Wawer MJ, Sewankambo NK, Serwadda D, et al. Control of sexually transmitted diseases for AIDS prevention in Uganda: a randomized community trial. Lancet 1999;353:525-35.

31 Hillier SL, Nugent RP, Eschenbach DA, et al. Association between bacteria vaginosis and preterm delivery of a low-birth-weight infant. $N$ Engl J Med 1995;333:1737-42

32 Martius J, Krohn MA, Hillier SL, et al. Relationships of vaginal Lactobacillus species, cervical Chlamydia trachomatis, and bacterial vaginosis to preterm birth. Obstet Gynecol 1988;71:89-95.

33 McGregor JA, French Jl, Seo K. Premature rupture of membranes and bacterial vaginosis. Am J Obstet Gynecol 1993;169(pt 2):463-8.

34 McGregor JA, French Jl, Parker R, et al. Prevention of premature birth by screening and treatment for common genital tract infections: results of a prospective controlled evaluation. Am J Obstet Gynecol 1995;173:157-67.

35 Gravett MG, Nelson HP, DeRoven T, et al. Independent associations of bacterial vaginosis and Chlamydia trachomatis infection with adverse pregnancy outcome. JAMA 1986;256:1899-903.

36 Hauth JC Goldenberg RL, Andrews WW, et al. Reduced incidence of preterm delivery with metronidazole and erythromycin in women with bacterial vaginosis. N Engl J Med 1995;333:1732.

37 Oakeshott $\mathrm{P}$, Hay $\mathrm{P}, \mathrm{Hay} \mathrm{S}$, et al. Association between bacterial vaginosis or chlamydia infection and miscarriage before 16 weeks gestation: prospective community based cohort study. BMJ 2002;325:1334.

38 Joesoef MR, Hillier SL, Wiknjosastro S et al. Intravaginal clindamycin treatment for BV: effects on preterm delivery and low birth weight Am J Obstet Gynecol 1995; 173:1527-31.

39 Riduan JM, Hillier SL, Utomo B, et al. Bacterial vaginosis and prematurity in Indonesia: association in early and late pregnancy. Am J Obstet Gynecol 1993; 169:175-8.

40 Donders GGG. Bacterial vaginosis during pregnancy: screen and treat? Eur J Obstet Gynecol Reprod Biol 1999:83:1-4.

41 Schwebke JR. Update of trichomoniasis. Sex Transm Infect 2002;78:378.

42 Krieger JN, Alderete JF. Trichomonas vaginalis and trichomoniasis. In:Holmes KK, Sparing PF, Mardh P-A, et al.Sexually transmitted diseases.3rd ed.1999; Chapter 43, 587-604.

43 Swygard H, Sena AC, Hobbs MM, et al. Trichomoniasis: clinical manifestations, diagnosis and management. Sex Transm Infect 2004;80:91-5.

44 Cotch MF, Pastorek JG, Nugent RP, et al. Trichomonas vaginalis associated with low birth weight and preterm delivery. Sex Transm Dis 1997;24:341-61.

45 Minkoff H, Grunebaum AN, Schwarz RH, et al. Risk factors for prematurity and premature rupture of membranes: a prospective study of the vaginal flora in pregnancy. Am J Obstet Gynecol 1984;150:965-72.

46 Hardy PH, Hardy JB, Nell EE et al. Prevalence of six sexually transmitted disease agents among pregnant inner-city adolescents and pregnancy outcome. Lancet 1984;2:333-7.

47 Sutton MY, Sternberg M, Nsuami, et al. Trichomoniasis in pregnant human immunodeficiency virus-infected and human immunodeficiency virusuninfected congolese women: Prevalence, risk factors, and association with low birth weight. Am J Obstet Gynecol 1999;181:656-62.

48 Bowden FJ, Garnett GP. Why is Trichomonas vaginalis ignored? Sex Transm Infect 1999:75:372-4.

49 Klebanoff MA, Carey JC, Hauth JC, et al. Failure of metronidazole to prevent preterm delivery among pregnant women with asymptomatic Trichomonas vaginalis infection. N Engl J Med 2001;345:487-93.

50 Obasi A, Mosha F, Quigley M, et al. Antibody to herpes simplex virus type 2 as a marker of sexual risk behavior in rural Tanzania. J Infect Dis 1999; 179: 16-24.

51 Smith JS, Robinson NJ. Age-specific prevalence of infection with herpes simplex virus types 2 and 1: a global review. J Infect Dis 2002;186(Suppl 1):S3-28.

52 O'Farrell N. Increasing prevalence of genital herpes in developing countries: implications for heterosexual HIV transmission and STI programmes. Sex Transm Infect 1999;75:377-84.

53 Rahman M, Paz-Bailey G, Regoeng M, et al. Changing patterns of STD in Botswana, 1993-2003. Abstract (No. 0334) presented at 15th Biennial Congress of the International Society for Sexually Transmitted Diseases Research (ISSTDR), OHtawa, Canada, 27-30 July, 2003.

54 Weiss HA, Buve A, Robinson NJ, et al. Study group on heterogeneity of HIV epidemics in African cities. The epidemiology of HSV-2 infection and its association with HIV infection in four urban African populations. AIDS 2001;15(Suppl 4):S97-108

55 Del Mar Pujades Rodrigues M, Obasi A, Mosha F, et al. Herpes simplex virus type 2 infection increases HIV incidence: a prospective study in rural Tanzania. AIDS 2002;16:451-62.

56 Wald A, Link K. Risk of human immunodeficiency virus infection in herpes simplex virus type-2 seropositive persons. A meta-analysis. J Infect Dis 2002; 185:45-52.

57 Sheffield JS, Hollier LM, Hill JB, et al. Acyclovir prophylaxis to prevent herpes simplex virus recurrence at delivery: a systematic review. Obstet Gynecol 2003; 102:1396-403

58 Scott LL. Prevention of perinatal herpes: prophylactic antiviral therapy? Clin Obstet Gynaecol 1999;42:134-48.

59 Brown ZA, Wald A, Morrow, et al. Effect of serologic status and cesarean delivery on transmission rates of herpes simplex virus from mother to infant. JAMA 2003;289:203-9.

60 Mindel A, Taylor J, Tideman RL, et al. Neonatal herpes prevention: a minor public health problem in some communities. Sex Transm Infect 2000;76:287-91.
61 Kulhaniian JA, Soroush V, Au DS, Bronzan RN, et al. Identification of women at unsuspected risk of primary infection with herpes simplex type-2 virus during pregnancy. N Engl J Med 1992;326:916-20.

62 Brown ZA, Selke S, Zeh J, et al. The acquisition of herpes simplex virus during pregnancy. N Engl J Med 1997;337:509-15.

63 Fawzi W, Msamanga G, Spiegelman D, et al. Transmission of HIV-1 through breastfeeding among women in Dar es Salaam, Tanzania J. Acquir Immune Defic Syndr 2002;31:331-8.

64 UNAIDS 2003. Follow up to the 2001 United Nations General Assembly Special Session on HIV/AIDS. Progress Report on the Global Response to the HIV/AIDS Epidemic, 2003.

65 Ladner J, Leroy V, Hoffman P, et al. Chorioamnionitis and pregnancy outcome in HIV-infected African women. J Acquir Immune Defic Syndr Hum Retrovirol 1998; 18:293-8.

66 Mwanyumba F, Gaillard P, Inion I, et al. Placental inflammation and perinatal transmission of HIV-1. J Acquir Immune Defic Syndr 2002;29:262-9.

67 Temmerman M, Plummer FA, Mirza NB, et al. Infection with HIV as a risk factor for adverse obstetrical outcome. AIDS 1990:4:1087-3.

68 Temmerman M, Chomba EN, Ndinya-Achola J, et al. Maternal human immunodeficiency virus-1 infection and pregnancy outcome. Obstet Gynecol 1994:83:495-501.

69 Leroy V, Ladner J, Nyiraziraje M, et al. Effect of HIV-1 infection on pregnancy outcome in women in Kigali, Rwanda, 1992-1994. AIDS 1998; 12:643-50.

70 Temmerman M, Ali FM, Ndinya Achola J, et al. Rapid increase of both HIVinfection and syphilis among pregnant women in Nairobi, Kenya. AIDS 1992;6:1181-5

71 De Cock KM, Fowler MG, Mercier E, et al. Prevention of mother-to-child HIV transmission in resource-poor countries: translating research into policy and practice. JAMA 2000;283:1175-82.

72 Ogundele MO, Coulter JBS. HIV transmission through breastfeeding: problems and prevention. Ann Trop Paediatr 2003;23:91-106

73 De Cock KM, Fowler MG, Mercier E. Prevention of mother-to-child HIV transmission in resource-poor countries: translating research into policy and practice. JAMA 2000;283:1175-82.

74 Embree JE, Nienga S, Datta P, et al. Risk factors for postnatal mother-child transmission of HIV-1. AIDS 2000;14:2535-1.

75 Semba RD, Kumwenda N, Hoover DR, et al. Human immunodeficiency virus load in breast milk, mastitis, and mother-to-child transmission of human immunodeficiency virus type 1. J Infect Dis 1999;180:93-8.

76 John GC, Nduati RW, Mbori-Ngacha DA, et al. Correlates of mother-tochild human immunodeficiency virus type 1 (HIV-1) transmission: association with maternal plasma HIV-1 RNA load, genital HIV-1 DNA shedding, and breast infections. J Infect Dis 2001;183:206-12

77 Coutsoudis A, Pillay K, Spooner E, et al. Influence of infant-feeding patterns on early mother-to-child transmission of HIV-1 in Durban, South Africa: a prospective cohort study. South African Vitamin A Study Group. Lancet 1999:354:471-6.

78 Nolan ML, Greenberg AE, Fowler MG. A review of clinical trials to prevent mother to child HIV transmission in Africa and inform rational intervention strategies. AIDS 2002;16:1991-9.

79 Centers for Disease Control and Prevention. Sexually transmitted diseases treatment guidelines 2002. MMWR Recomm Rep 2002;51(RR-6):1-78.

80 World Health Organization. Guidelines for the management of sexually transmitted infections, WHO/HIV AIDS/2001.01. Geneva: WHO, 2001.

81 Wilkinson D, Sach M, Connolly C. Epidemiology of syphilis in pregnancy in rural South Africa: opportunities for control. Trop Med Int Health 1997;2:57-62

82 Jenniskens $\mathbf{F}$, Obwaka E, Kirisuah S, et al. Syphilis control in pregnancy: decentralization of screening facilities to primary care level, a demonstration project in Nairobi, Kenya. Int J Gynaecol Obstet 1995;48(Suppl):S121-8.

83 Rotchford K, Lombard C, Zuma K, et al. Impact on perinatal mortality of missed opportunities to treat maternal syphilis in rural South Africa: baseline results from a clinic randomised controlled trial. Trop Med Int Health 2000;5:800-4.

84 Myer L, Wilkinson D, Lombard C, et al. Impact of on-site testing for maternal syphilis on treatment delays, treatment rates, and perinatal mortality in rural South Africa: a randomised controlled trial. Sex Transm Infect 2003;79:208-13.

85 Watson-Jones D, Gumodoka B, Weiss H, et al. Syphilis in pregnancy in Tanzania. II. The effectiveness of antenatal syphilis screening and single-dose benzathine penicillin treatment for the prevention of adverse pregnancy outcomes. J Infect Dis 2002;186:948-57.

86 Terris-Prestholt F, Watson-Jones D, Mugeye K, et al. Is antenatal syphilis screening still cost effective in sub-Saharan Africa. Sex Transm Infect 2003;79:375-81.

87 Guay LA, Musoke P, Fleming T, et al. Intrapartum and neonatal single-dose nevirapine compared with zidovudine for prevention of mother-to-child transmission of HIV-1 in Kampala, Uganda: HIVNET 012 randomised trial. Lancet 1999;354:795-802.

88 Editorial. J Infect Dis 2003;187:721-4.

89 Moodley D, Moodley J, Coovadia H, et al. A multi-center randomized controlled trial of nevirapine versus a combination of zidovidine and lamivudine to reduce intrapartum and early postpartum mother-to-childtransmission of human immunodeficiency virus type 1. J Infect Dis 2003;187:725-35.

90 Farley T, Buyse D, Gaillard P. Efficacy of antiretroviral regimens for prevention of mother to child transmission of HIV and some programmatic issues. Background paper prepared for Technical Consultation on New Data 
on the Prevention of Mother to Child Transmission of HIV and their Policy Implications. Geneva, 11-13 October, 2000.

91 World Health Organization. Antiretroviral drugs and the prevention of mother to child transmission of HIV infection in resource constrained settings: Recommendations for use 2004 revision, Draft version-for public consultation. Geneva: WHO, 2004.

92 Scotland GS, van Teijlingen ER, van der Pol M, et al. A review of studies assessing the costs and consequences of interventions to reduce mother-tochild HIV transmission in sub-Saharan Africa. AIDS 2003;17:1045-2.

93 Jourdain G, Ngo-Giang-lluong N, Le Coeur S, et al. Intrapartum exposure to nevirapine and subsequent maternal responses to Nevirapine-based antiretroviral therapy. N Engl J Med 2004;351:229-40.

94 Stringer EM, Sinkala M, Stringer JS, et al. Prevention of mother-to-child transmission of HIV in Africa: successes and challenges in scaling-up a nevirapine-based program in Lusaka, Zambia. AIDS 2003;17:1377-2.

95 Rutenberg N, Baek C, Kalibala S, et al. HIV Voluntary counseling and testing: an essential component in preventing mother-to-child transmission of HIV. Horizons Research Summary. Washington, DC: Population Council, 2003.

96 World Health Assembly. Infant and young child nutrition. Geneva: World Health Organization, Resolution WHA54, 2, 2001.

97 World Health Organization. New data on the prevention of mother-to-child transmission of HIV and their policy implications: conclusions and recommendations, WHO Technical Consultation on behalf of the UNFPA/ UNICEF/WHO/UNAIDS Inter-Agency Task Team on Mother-to-Child Transmission of HIV.Report No WHO/RHR/01.28. Geneva: WHO, 2001

98 Amsel R, Totten PA, Spiegel CA, et al. Nonspecific vaginitis. Diagnostic criteria and microbial and epidemiologic associations. Am J Med 1989;74:14-22.

99 Nugent RP, Krohn MA, Hillier SL. Reliability of diagnosing bacterial vaginosis is improved by a standardized method of gram stain interpretation. J Clin Microbiol 1991;29:297-301.

100 Ndowa F. The syndromic management of genital discharge and genital ulce diseases. Abstract (No. 0759) presented at 15th Biennial Congress of the International Society for Sexually Transmitted Diseases Research (ISSTDR), Ottawa, Canada. 27-30 July, 2003.

101 Vuylsteke B. Current status of syndromic management of sexually transmitted infections in developing countries. Sex Transm Infect 2004;80:333-4.
102 Gaillard P, Mwanyumba F, Verhofstede C, et al. Vaginal lavage with chlorhexidine during labour to reduce mother-to-child HIV transmission: clinical trial in Mombasa, Kenya. AIDS 2001;15:389-96.

103 Gichangi PB, Ndinya-Achola JO, Ombete J, et al. Antimicrobial prophylaxis in pregnancy: a randomized, placebo-controlled trial with cefetamet-pivoxil in pregnant women with a poor obstetric history. Am J Obstet Gynecol 1997; 177:680-4.

104 Laga M, Meheus A, Piot P. Epidemiology and control of gonococcal ophthalmia neonatorum. Bull World Health Organ 1989:67:471-7.

105 Isenberg SJ, Apt L, Wood M. The influence of perinatal infective factors on opthalmia neonatorum. J Pediatr Opthalmol Strabismus 1996;33:185-8.

106 Hira SK, Bhat GJ, Chikamata DM, et al. Syphilis intervention in pregnancy: Zambian demonstration project. Genitourin Med 1990;66:159-4.

107 Gaillard P, Melis R, Mwanyumba F, et al. Vulnerability of women in an African setting: lessons for mother-to-child HIV transmission prevention programmes. AIDS 2002;16:937-9.

108 Wolday D, G-Mariam Z, Mohammed Z. Risk factors associated with failure of syndromic treatment of sexually transmitted diseases among women seeking primary care in Addis Ababa. Sex Transm Infect 2004;80:392-4

109 Rastogi S, Das B, Salhan S, et al. Effect of treatment for Chlamydia trachomatis during pregnancy. Int J Gynaecol Obstet 2003;80:129-37.

110 Latif AS, Mason PR, Marowa E, et al. Risk factors for gonococcal and chlamydial cervical infection in pregnant and non-pregnant women in Zimbabwe. Cent Afr J Med 1999:45:10.

111 Msuya SE, Mbizvo E, Stray-Pedersen B, et al. Reproductive tract infections among women attending primary health care facilities in Moshi,Tanzania. East Afr Med J 2002;79:16-21.

112 Blankhart D, Muller O, Gresenguet $G$, et al. Sexually transmitted infections in young pregnant women in Bangui, Central African Republic. Int J STD AIDS 1999; 10:609-14

113 Marai W. Lower genital tract infections among pregnant women: a review. East Afr Med J 2001;78:581.

114 Ayisi JG, van Eijk AM, ter Kuile FO, et al. The effect of dual infection with HIV and malaria on pregnancy outcome in Western Kenya. AIDS 2003;17:585-94.

115 World Health Organization. Integrating care for reproductive health, sexually transmitted and other reproductive tract infections; a guide to essential practice. Geneva: WHO, January, 2004.

\section{bmjupdates+}

bmjupdates+ is a unique and free alerting service, designed to keep you up to date with the medical literature that is truly important to your practice.

bmjupdates+ will alert you to important new research and will provide you with the best new evidence concerning important advances in health care, tailored to your medical interests and time demands.

Where does the information come from?

bmiupdates+ applies an expert critical appraisal filter to over 100 top medical journals A panel of over 2000 physicians find the few 'must read' studies for each area of clinical interest

Sign up to receive your tailored email alerts, searching access and more...

www.bmjupdates.com 